\title{
Disability: A Case Screening Program Approach
}

\author{
Sudarshan Paudel ${ }^{1}$, Lilanath Bhandari², Dil Bahadur Bhandari1 \\ ${ }^{1}$ Department of Community Health Sciences, Patan Academy of Health Sciences, Lalitpur, Nepal \\ ${ }^{2}$ Department of Public Health, HOPE International College, Lalitpur, Nepal \\ Email: sudarshanpaudel@pahs.edu.np, lilanathbhandari@gmail.com,dilbbhandari@pahs.edu.np
}

How to cite this paper: Paudel, S., Bhandari, L. and Bhandari, D.B. (2017) Disability: A Case Screening Program Approach. Journal of Biosciences and Medicines, 5, $10-21$.

https://doi.org/10.4236/jbm.2017.52002

Received: December 19, 2016

Accepted: February 6, 2017

Published: February 9, 2017

Copyright (C) 2017 by authors and Scientific Research Publishing Inc. This work is licensed under the Creative Commons Attribution International License (CC BY 4.0).

http://creativecommons.org/licenses/by/4.0/

\begin{abstract}
Disability is an accident waiting to happen in population. Large numbers of population in world are disabled and its prevalence is on the rise. Disabled people have to face two additional challenges namely, limitation in body and social stigmatization on top of other social happening to general public. The stipulation of disability will be subjective because social and physical condition is directly related to it. The study was also envisioned to develop a disability screening approach. The objective was to focus on how disabled has been included in the government's health plans in Nepal. The study has presented data of 894 disabled people from randomly selected seven VDCs of Makwanpur district. The total population in studied VDCs was 87,502 . The study was conducted in coordination with local governing bodies and health development partners during August-October in 2012. The study revealed 1.02 percent prevalence of disability among study population. The majority were suffering physical disability (60.6 percent) followed by deaf (19.7 percent). Based on age group, young adults (15 - 19 years) group was more (31 percent) vulnerable. Out of total, the number of male was higher due to their high exposure in external environment and risk taking behaviour.
\end{abstract}

\section{Keywords}

Disability, Case Screening, Nepal

\section{Introduction}

The latest census of Nepal (2011) has accepted that people with disabilities are economically and socially vulnerable, underprivileged and marginalized population in the country [1] [2]. The same phenomenon is found across the world. People with disabilities have poorer health outcomes, lower attainment of education, lesser opportunities to participate in economic activities and withdrawal from basic social services in their everyday lives due to the lack of accessibility, availability and affordability as compared to people without disabilities [3]. The 
report furthermore emphasizes that condition of socio-economically underprivileged people is further worse.

An estimated $15 \%$ of the world's population-approximately one billion people, of whom 200 million are children-experience some form of disability which was around 10\% during 1970s [4]. The disability prevalence will increase in coming days due to increasing number of ageing population and high prevalence of lifestyle related diseases conditions worldwide. Besides that trends of environmental dilapidation, poor developmental infrastructure, fragile health care system, social unrest, risky socio-cultural practices in some ethnic groups will continue augmenting disability [3] [4].

Disability can be measured in different ways, affecting both the number of incidences and distributions on various variables. Thus, the disability rates from diverse national data collection sources are not yet comparable across the world because of differences in definition, concepts and methods [5] [6].

The study focused on how disabled has been included in the government's health plans in Nepal. The second part of the article presents data from a small study of disabled people. The study was conducted in Makawanpur, a hilly district of Nepal in coordination with local governing bodies, health development partners and disable people self-help groups.

\section{Disability and Disabled People}

Disability and poverty are inextricably linked and lead to a vicious cycle with one being both a cause and a consequence of the other [3] [5]. Persons with disabilities are estimated to make up to $15 \%$ to $20 \%$ of poor people in developing countries [3] [7]. Worldwide, as much as $50 \%$ of disabilities are directly linked to poverty [8]. The relationships between poverty and disability are complex, including social exclusion and stigma, and barriers to employment. Disability and poverty is examined by two methods. If the poverty is analyzed in terms of availability of money, good or services earning and consuming, it is called monetary method. This method is used to measure household level poverty. This method, however, lacks the explanatory variables that breed poverty [9]. The other method of measuring poverty is quality of life and focuses on opportunity for dignity, freedom, self-respect and respect to others, and decent living [10].

It is a distressing fact that the number of people with disabilities is growing due to population growth, ageing, emergence of chronic diseases, and medical advances that preserve and prolong life. The most common causes of impairment and disability are: chronic diseases such as diabetes, cardiovascular disease and cancer; injuries due to road traffic accidents, violence, falls and landmines; birth defects; malnutrition; and communicable diseases such as HIV/AIDS and leprosy [3] [7] [8]. Furthermore, many people were disabled during the ten year long civil war [11].

Over the past few decades, organizations for Persons with Disabilities (PWDs) have increasingly taken a collective view of disability and focused on the role of barriers (physical, social, attitudinal and cultural) created by the society [12] 
[13]. The organizations have proposed interventions for a more equitable society that dismantles disabling barriers and respects human rights for everyone. This awareness has developed the medical model of disability [12]. The medical model looks at disability at the individual level, proposing interventions that can improve individuals' functioning ability and decrease the impact of the disabilities (to those who can afford). The social model of disability has had a profound impact on the way disability issues are understood and analyzed. It has also led to the development of the "International Classification of Functioning, Disability and Health" (ICF, 2001) by the World Health Organization (WHO) [14]. In the context of health, under ICF, disability is seen as a complex relationship between the health condition and the contextual factors (i.e. environmental) and personal factors [15] [16].

\section{Disability in Nepal}

Nepal, with a population of about 26 million, is one of the underdeveloped countries in the world with a per capita income of US $\$ 762$ per year in fiscal year 2015 [17]. The poverty incidence or poverty headcount rate for Nepal is 25.2 percent [18]. More than $60 \%$ (31\% according to the government data) of the population live in abject poverty, which affects different human development indices [19]. Over the past decade, life in Nepal has been marked by internal strife and civil war with suspension of civil liberties, which have been reinstated only recently. This has worsened the general situation in the country.

The ten year long insurgency has affected the lives of many people all over the country and many have become disabled, caught in ambush or in crossfire between national security forces and Maoists [20]. Nepal is prone to environmental and natural disasters such as landslides, floods, and earthquake, which have direct implications for the prevalence of disability.

There has been varying estimates of disabled persons in the past studies in Nepal. The 1971 census referred to the population of persons in Nepal with disabilities as the economically inactive population due to physical disability. This definition included four types of disability: blindness, deafness, deaf-mute, or other physical impairments. The study indicated a national disability rate of $1.5 \%$ of the total population over 10 years of age (JICA, 2002). The National Population Census of 1981, 1991 and 2001 stated rates of disability at $0.5 \%, 1.5 \%$ and $0.46 \%$, respectively [21]. The 2011 Population Census reported $1.94 \%$ disability prevalence rate of the total population [6]. Some specialized studies show $16.6 \%$ of Hearing Impairment [22], 4.9\% of Intellectual Disability, 25\% with psychosocial problems, and $1 \%$ of Visual Impairment in Nepal. The condition of People with Disability (PWDs) in Nepal is serious: approximately 68.2\% PWDs have no access to education, $85 \%$ have no access to health care facilities, and $77.8 \%$ have no employment to earn their living [23]. The same report mentioned that, due to no social protection, many disabled people either died untimely or veiled to die by their own [24]. In summary, PWDs are not being an included part of the community. 
Disability is complex and multifaceted, with its effect on various span of life. Culture of the land has great role over the factors contributing to disability. Merging all factors into one indicator that can measure longevity is difficult. A better approach would be to rethink what measures are needed for different objectives and how to best calculate them [23]. This type of measures would enable citizens to demand health and rehabilitation services. Today, such services are not available, particularly among the poor and other disadvantaged groups. Until now, Nepali disabled people are far behind to make their voice heard because they are rescind within family [2] [6].

In 2006, the government of Nepal made a National Policy and Plan of Action on Disability [25]. It identified 17 areas for the development of PWDs' conditions. This document was based on the Declaration of Asian and Pacific Decade of Disabled Persons, (1993-2002); the World Action Plan on Disability (1982); the UN's Standard Rules on the Equalization of Opportunities for PWD; and the seven priority areas determined by Biwako Millennium Framework of Action, [15] as well as national policies and plans. However, these plans are hardly reflected in actual practice. The document had specified the responsibilities of different stakeholders, stating that all agencies, sectors and parties have to collaborate while implementing the plan, for instance, decide how to approach families in communities in order to unveil cases of disability, and how to ensure the survival of disabled newborn. The implementation is faced with several challenges: lack of financial resources and means, lack of coordination, lack of mass awareness, flaws in government institutional structures that leads to delay in necessary amendments of acts and regulation and formulation of new laws, policies and regulations, etc. Issues related to transparency, accountability, organisation coordination, exchange of experiences both at the national and international levels, appropriate mobilisation of non government organisations and civil society, all are essential steps for the government to effectively implement its plan.

The constitution of Nepal promulgated in 2015 has guaranteed "right to health care" as a fundamental right and provides each citizen the "right to seek health care services from the state and no citizen shall be deprived of emergency health care." The constitution has envisioned dignified life and equal access to social services and facilities to people with physical impairment along with their diversity identity [13].

\section{Disability Study in Makawanpur}

Makawanpur is a hilly district of Nepal with a population of approximately 447,383 (Table 1) which includes various ethnic groups (more than 15 tribes), each with its own language and culture. The Tamang people represent a majority with 47 percent of the district's population, whereas the Bankariya and the Chepang are ethnic minorities who feel their life conditions somewhat imperilled [26].

Politically, the district is divided into 44 village development committees (VDCs) and one municipality. The male/female ratio is 1.02 ( $49.28 \%$ female), 
Table 1. Demographic information of the Makawanpur district.

\begin{tabular}{ccc}
\hline SN & Demographic indicators & Numbers \\
\hline 1 & Under one year & 14,316 \\
2 & Under three years & 41,727 \\
3 & Under five years & 67,853 \\
4 & Female pop ${ }^{\mathrm{n}}(15-44$ yrs $)$ & 96,773 \\
5 & Expected pregnancies & 15,370 \\
6 & Adolescent (10 - 19 yrs) & 101,604 \\
7 & Married women of reproductive age & 83,904 \\
& Total population & $\mathbf{4 4 7 , 3 8 3}$ \\
\hline
\end{tabular}

and the population growth is $2.2 \%$. The average household size among the 71,112 families is 5 , with a total population of 447,383 [12]. The proportion of rural population is $82.6 \%$, and the density per square $\mathrm{km}$ is 160.5 people. The literacy rate in the district is $63.4 \%$ (female $53.9 \%$ ). $53.6 \%$ among the economically active population work in agriculture. Only $25.15 \%$ of the land can be cultivated [14].

\section{Sample Size}

To find the sample size, the district was divided into two parts demarking by Tribhuvan Highway ensuring equal number of VDCs. The population size and ethnic composition in both parts was almost alike. We reviewed government statistics to ensure disability awareness, care and support programs coverage from government sectors and other development agencies, and found consistent in both parts thus decided to select only one part. Through random method western part [from Tribhvan Highway] of district was selected for data collection. Out of total twenty-one VDCs of western part of Makwanpur, seven VDCs were selected randomly for data collection. The VDCs are almost homogenous in number and geography.

The data for this study were collected in a survey during August to October in 2012 in collaboration with district development committee, and the district disability steering committee. The study had covered all households from study VDCs. Almost all the households belong to marginalised rural groups, usually specific caste groups [14].

\section{Selection of Volunteers}

The health post incharge took lead to team up with local user groups, women groups, community based organizations (CBOs), village development committees (VDC) and other community groups and individuals. The communities had several meetings to identify volunteers. The meeting had set criterias to be eliigible for research volunteers; 1) willingness to work as volunteer, 2) local resident, 
3) good raport skills and 4) prior experince woriking in disability awareness and services. The Health Post In-charges published notice to express their interest by those who meet criteria. The District Disability Screening Committee in coordination with Healthpost In-charge interviewed all eligible incumbets and published name list of 8 volunteers ( 4 female and 4 male) at least one volunteers from all study VDCs. (Due to difficulty topography andn large number of household size, there were two volunteers in Hadikhola VDC). The selected volunteers were apppointed in Health Post who were subjected to get transportation, fooding and acomodation cost at actual basis.

Research volunteers were privided with intensive residential training for 13 days by District Disability Screenig Committee in coordination with National Disability Federation of Nepal. The content of the training were as follow:

- Concept, definition and development of Community Based Rehabilitation (CBR).

- Basic functions and structure of Human anatomy.

- Social and Community Approach on Disability.

- Definition and classification of disability, Social Model of Disability (Disability and Development, Disability and Poverty, Disability and Human rights, Disability related national and international policies, laws and rules).

- Visual disability and rehabilitation.

- Intellectual Disability and Rehabilitation.

- Hearing Disability and Rehabilitation.

- Mental Illness and psycho-social counseling.

- Physical Disability and Rehabilitation.

- Sound and Speaking Disability and Rehabilitation.

- Disability Identification and Comprehensive Assessment.

- Advocacy and Awareness for Disability Rights.

- Rights of Women/Girls with Disability.

- Deaf-Blindness and Rehabilitation.

- Disability Management in rural area: Program planning, managing, reporting, recording keeping etc.

After successfully complition of training, volunteers were mobilized under the aegis of district disability screening committee so that they felt responsible toward the community rather than surver organization. Three survey volunteers were parents of disabled children and the rest were from ethnic groups.

The preliminary tasks for the volunteers were to identify the PWDs, provide preventive services to PWDs, and to encourage the VDC in their own community to make disability a developmental issue. The volunteers periodically developed a community disability plan for VDC. This was done in collaboration with district disability streering committee. After six month of basic training, they were given 6 days refresher training and orientation about disability screening, using a disability assessment form (DAF).

The district disability steering committee provided furhter capacity building training to the volunters with emphasis on social communication about disabili- 
ty. They were also equiped with basic tool-kits for screening and creating awarness in their community and filled up all the assessed cases asking with household head of every household from study VDCs. The identification of disabled persons in a family was based on acceptance by the head of each household. If someone had not perceived or intentionally hidden information from the CDVs, relevant respondents could not be included in the study. Such cases are probably few, thus not affecting the study's results.

Disability can be conceptualized on a continuum from minor difficulties in functioning to major impacts on a person's life but for this survey, the national definition and classification of disability, developed by the Nepali Government in September 2006 on the basis of the International Classification of Functioning, Disability and Health (ICF) was followed. The classification has defined seven types of disabilities i.e. Physical disability, Visual Disability, Hearing Disability, Speech Disability, Deaf-blind, Intellectual Disability, and Multiple Disabilities. The new definition comprises persons with Muscular Dystrophy, Short people (Dwarfs), Autistic, Deaf and blind, Stutter, etc. Disaggregating these data further by sex, age, income, or occupation is important for uncovering patterns, trends, and other information about "subgroups" of people experiencing disability. The study differentiated people according to literate/illiterate, and to five educational levels: primary schooling (grade $1-5$ ), lower secondary schooling (grade $6-8$ ), secondary schooling (grade $9-10$ ), higher secondary schooling (grade 11 - 12), and university degree. The economic classification of a family was based on the amount of food production: 1) Very poor: family production of grain is hardly enough for three months or less; 2) Poor: family production is hardly enough for nine months per year.

\section{Results and Discussion}

Table 2 presents number of disabled people pooled in 2012 in study community. There are total 894 disabled people out of 87,502 which is 1.02 percentages. The table shows generally low percentages of disabled people, but four VDCs have above $1.2 \%$.

The figure (Table 2) shows that out of 7 VDC, three VDCs namely Bajrabarahi, Manahari and Basamadi have $\leq 1 \%$ of disabled people and remaining four VDCs namely Agra, Gogane, Hadikhola and Namtar have $>1.2 \%$ of disabled people. These four VDCs are geographically very difficult and hard to reach. The main source of income is agriculture but these are food deficit communities.

The data (Table 3 ) shows that there are more disabled among male than female, more among poor than people from other economic status and more among illiterate than literate people, and more among people with low than higher education. There were higher number of male disabled people in Agra, Manahari, Hadikhola, Basamadi and Namtar whereas Bajrabarahi and Gogane had the higher number of female disabled people.

We had categorized economic status into three group, poor for those who had no food security for more than three month by their own production and no 
regular source of income and standard were those who had satisfactory food security throughout the year.

More number of disabled people were found to be in the age group between 10 - 19 years comprising about $31 \%$ of the total disabled people (Table 4).

Based on ethinic distribution of population, Tamangs were found to have the highest percentage of disability followed by Brahmins and Chhetri (Figure 1).

The study has revealed that $60.6 \%$ people have physical disability (Figure 2). For the study purpose, physical disability means being limitation to perform the activities of daily life due to physical deficiency, defect or deformity by birth, or by accident after birth, or due to disease, followed by deaf (19.7\%). For the study purpose deaf means person who have limitation to hear, speak clearly or cannot speak at all. Least among other but very large number of people have mental (3.6\%) disability. This category is defined as people who have limitation to perform the activities of daily life due to mental deficiency, defect or deformity by birth, by accident after birth, or by disease.

Table 2. VDC-wise disabled people in Makawanpur district.

\begin{tabular}{cccc}
\hline Name of VDCs & Number disabled & $\begin{array}{c}\text { Total population } \\
\text { in the VDCs }\end{array}$ & $\begin{array}{c}\text { \% disabled people out } \\
\text { of total population }\end{array}$ \\
\hline Agra & 111 & 8926 & 1.24 \\
Bajrabarahi & 69 & 7854 & 1.02 \\
Basamadi & 74 & 17,797 & 1.31 \\
Gogane & 250 & 5648 & 1.20 \\
Hadikhola & 94 & 20,839 & 0.54 \\
Manahari & 114 & 17,349 & 1.25 \\
Namtar & 894 & 9089 & 1.02 \\
Total & & 87,502 & \\
\hline
\end{tabular}

Table 3. Disabled people, by sex, economic and educational status in percentage.

\begin{tabular}{|c|c|c|c|c|c|c|c|c|c|c|c|}
\hline \multirow{2}{*}{$\begin{array}{c}\text { Name of } \\
\text { VDCs }\end{array}$} & \multirow{2}{*}{ Total } & \multicolumn{2}{|c|}{ Sex } & \multicolumn{3}{|c|}{ Economic status } & \multicolumn{5}{|c|}{ Education status } \\
\hline & & Male & Female & Poor & Medium & Standard & Illiterate & Literate & Primary & Secondary & $\begin{array}{l}\text { Higher } \\
\text { second }\end{array}$ \\
\hline Agra & 111 & 61.3 & 38.7 & 23.4 & 64 & 12.6 & 70.3 & 12.6 & 17.1 & 0 & 0 \\
\hline Bajrabarahi & 69 & 44.1 & 57.4 & 61.1 & 31.4 & 7.5 & 67.6 & 15.2 & 11.2 & 3.1 & 2.9 \\
\hline Basamadi & 182 & 55.5 & 44.5 & 62.3 & 25.4 & 12.3 & 66.2 & 23.7 & 5.8 & 3.8 & 0.5 \\
\hline Gogane & 74 & 48.6 & 61.4 & 58.4 & 32.4 & 9.2 & 53.3 & 23.1 & 14.3 & 7.9 & 1.4 \\
\hline Hadikhola & 250 & 57.6 & 42.4 & 81.6 & 18 & 0.4 & 50 & 7.2 & 27.2 & 13.6 & 2 \\
\hline Manahari & 94 & 59.6 & 40.4 & 46.8 & 48.9 & 4.3 & 85.1 & 0 & 11.7 & 3.2 & 0 \\
\hline Namtar & 114 & 54.4 & 45.6 & 57.5 & 32.9 & 9.6 & 66 & 21.4 & 2.6 & 9.1 & 0.9 \\
\hline
\end{tabular}


Table 4. Disabled people by age. Percent.

\begin{tabular}{ccc}
\hline Age groups & Percent & Number of disabled \\
\hline$<5$ & 5.82 & 52 \\
$6-10$ & 8.72 & 78 \\
$10-14$ & 17.00 & 152 \\
$15-19$ & 14.65 & 131 \\
$20-24$ & 7.61 & 68 \\
$25-29$ & 5.37 & 48 \\
$30-34$ & 4.70 & 42 \\
$35-39$ & 7.61 & 68 \\
$40-49$ & 10.85 & 97 \\
$50-59$ & 6.94 & 62 \\
$60-69$ & 5.37 & 48 \\
$70-79$ & 4.03 & 36 \\
$>80$ & 1.34 & 12 \\
Total & 100 & 894 \\
\hline
\end{tabular}

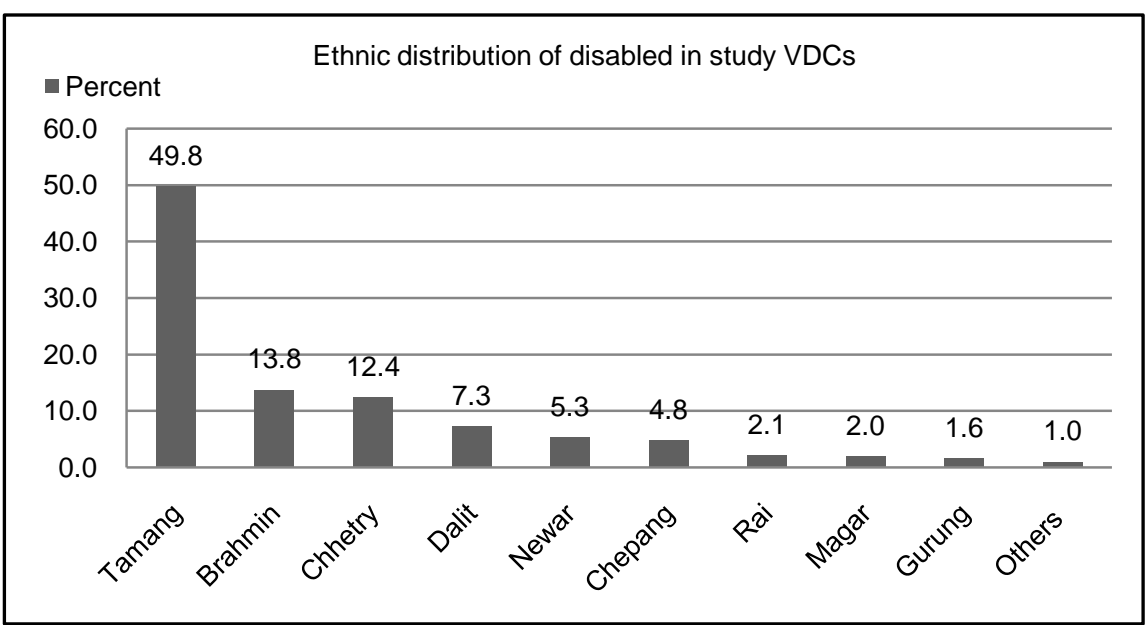

Figure 1. Disabled people by ethnic group. Percent.

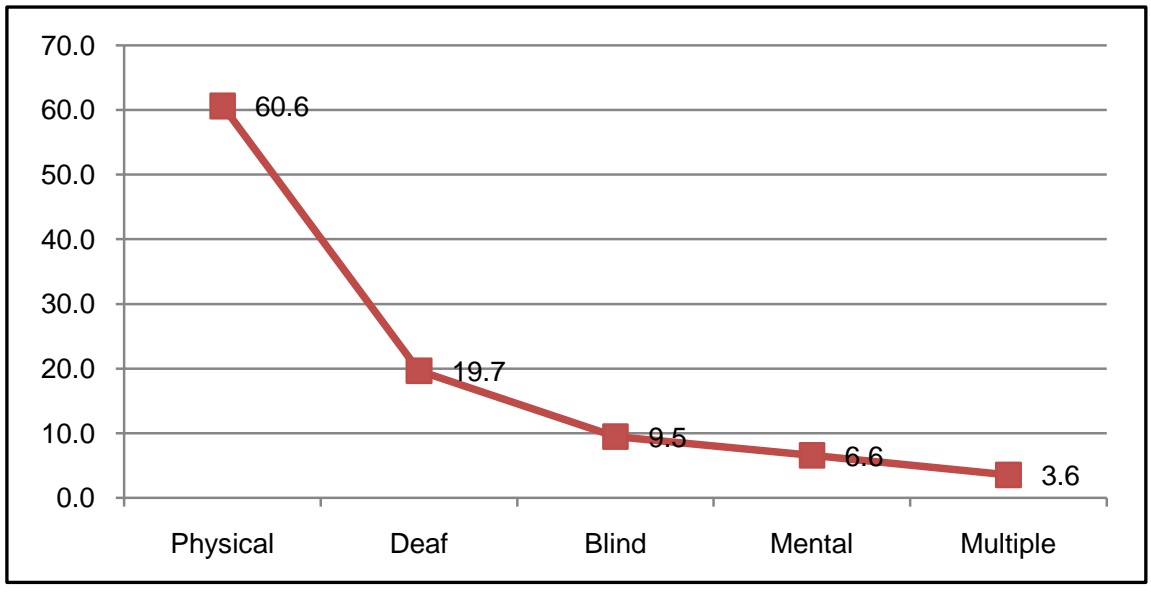

Figure 2. Types of disability in the VDCs and Percent of total number of disabled. 


\section{Conclusion}

People with disabilities are large in number in rural communities. The heterogeneity of the conceptual framework and insufficient recognition of the importance of indicator accuracy, the age factor, and the socio-economic characteristics of the populations under study, all affected the prevalence disability rate in Makwanpur. Disabled are considered as burden by the families, society and state. The disability condition is related to economic strata of population. Mainly people from lower socio-economic condition are in risk of serious problems including disability. The study has revealed that majority of the disabled person had physical disability following deaf and blind. Based on age group, young adults (15 - 19 years) group was more vulnerable. Out of total, the number of male was higher due to their high exposure in external environment and risk taking behaviour. The poverty and unavailability of health care services and illiteracy are other underpinning grounds to elevate the number. To revert the scenario, individual, family, society and nation have to give attention in nutrition, preventable diseases, environmental factors and workplace. Nepal has initiated prevention of health conditions of people associated with disability but there are lots of efforts needed to be laid to educate people about disability and its management which helps to reduce socio-cultural, environmental detergents in harmony with the needs of disabled persons. Disability management should be multisectoral interventions and it should be reflected policies and priority programs.

\section{Acknowledgements}

Prof. Marit Bakke from Norway (marit.bakke@media.uib.no) has supported to elevate the issues of disabled people of Nepal, and gave valuable inputs on its first draft.

Prof. Madhusudan Subedi, Department of Sociology and Anthropology, Tribhuvan University, Nepal encouraged us for the study and helped to review the manuscript and feedback.

Shudarshan Subedi, President of Federation of Nepal Disabled Association for their wise contribution in reviewing the article.

\section{References}

[1] National Population and Housing Census (National Report) (2011) Central Bureau of Statistics, National Planning Commission Secretariat, Government of Nepal, Kathmandu, Nepal. http://cbs.gov.np/image/data/Population/National\%20Report/National\%20Report.p df

[2] Ministry of Health, Government of Nepal (2016) Vulnerable Community Development Plan. Nepal Health Sector Management Project, Kathmandu Nepal. http://www.docr.gov.np/sites/default/files/docr_notice.pdf

[3] World Health Organization (2011) World Report on Disability. http://www.who.int/disabilities/world_report/2011/report.pdf

[4] World Health Organization (2009) Report on Community-Based Rehabilitation 
WP/2009/DHP/10 Report Series No.: RS/2009/GE/37(PHL).

http://www.wpro.who.int/NR/rdonlyres/2707CE22-97F4-4046-9ADD-5C6C8A49E 7B7/0/FinalCBRReportJune2009_010210.pdf

[5] World Health Oraganization (2006) Disability and Poverty-WHO Fact Sheet, Disability and Rehabilitation Team, World Health Organisation (WHO/DAR), Geneva.

[6] Subedi, M. (2012) Challenges to Measure and Compare Disability: A Methodological Concern. Dhaulagiri Journal of Sociology and Anthropology, 6, 1-24.

[7] Elwan, A. (1999) Poverty \& Disability: A Survey of the Literature. World Bank.

[8] DFID (2000) Disability, Poverty and Development, UK Department for International Development (DFID).

[9] Laderchi, C.R. (2000) The Moneraty Approach to Poverty. A Survey of Concepts and Methods. QEH Working Paper Series, QEHWPS58, University of Oxford.

[10] Sen, A. (2012) Development as Freedom. Oxford University Press, New Delhi.

[11] UNDP (2009) Nepal Human Development Index (NDHI) Report. http://www.undp.org.np/publication/html/nhdr2009/NHDR2009.pdf

[12] National Policy and Plan of Action on Disability (2006) Government of Nepal, Ministry of Women, Children and Social Welfare, Kathmandu.

[13] The Constitution of Nepal (2015).

http://www.lawcommission.gov.np/en/documents/2016/01/constitution-of-nepal-2. pdf

[14] World Health Organization (2007) International Classification of Functioning, Disability and Health: Children \& Youth Version. http://apps.who.int/iris/bitstream/10665/43737/1/9789241547321_eng.pdf?ua=1

[15] ESCAP (2002) High-Level Intergovernmental Meeting to Conclude the Asian and Pacific Decade of Disabled Persons, 1993-2002. ESCAP, Otsu City, Shiga. http://www.unescap.org/esid/psis/disability/bmf/bmf.html on 28/12/2010

[16] Mitra, S. (2003) The Capability Approach to Disability. Journal of Disability Policy Studies, 16, 236-247. https://doi.org/10.2139/ssrn.2330438 http://cfs.unipv.it/sen/papers/Mitra.pdf

[17] Economic Survey (2015) Ministry of Finance, Government of Nepal. http://www.mof.gov.np/uploads/document/file/Final\%20Economic\%20Survey\%202 071-72\%20English\%20(Final)_20150716082638.pdf

[18] Government of Nepal (2014) Nepal Human Development Report, beyond Geography. National Planning Commission. www.npc.gov.np

[19] Shrestha, S. (2003) Accessibility of Health Services in Nepal. In: Deepak S., Ed., Poverty, Health and Development, Health Cooperation Papers Volume 17, AIFO, Italy.

[20] DSI (2007) Country Strategy of the Danish Council of Organization of Disabled People (October 2007-September 2012). The Study Made by Organization Development Centre (ODC), Nepal.

[21] Nepal Population Report (2011) Government of Nepal Ministry of Health and Population, Population Division Ramshahpath, Kathmandu.

www.mohp.gov.np

[22] Health Management Information System (2007) Projected Population (Based on 2001 Census) for Health Management Information System. Ministry of Health and Population, Nepal.

[23] Mont, D. (2007) Measuring Health and Disability. Lancet, 369, 1658-1663. 
https://doi.org/10.1016/S0140-6736(07)60752-1

[24] NPC \& UNICEF (2001) A Situation Analysis of Disability in Nepal. National Planning Commission of Nepal, Kathmandu.

[25] National Policy and Plan of Action on Disability (2006) Ministry for Women, Children and Social Welfare, Government of Nepal.

https://rcrdnepa.files.wordpress.com/2008/05/national-policy-and-plan-of-action20 06-eng.pdf

[26] DDC/MK (2007) Annual Report of District Development Committee Makwanpur, Nepal.

\section{Scientific Research Publishing}

Submit or recommend next manuscript to SCIRP and we will provide best service for you:

Accepting pre-submission inquiries through Email, Facebook, LinkedIn, Twitter, etc. A wide selection of journals (inclusive of 9 subjects, more than 200 journals)

Providing 24-hour high-quality service

User-friendly online submission system

Fair and swift peer-review system

Efficient typesetting and proofreading procedure

Display of the result of downloads and visits, as well as the number of cited articles

Maximum dissemination of your research work

Submit your manuscript at: http://papersubmission.scirp.org/

Or contact jbm@scirp.org 